\title{
PENERAPAN MODEL DISCOVERY LEARNING BERBANTUAN GEOGEBRA UNTUK MENINGKATKAN KEMAMPUAN PENALARAN MATEMATIS SISWA KELAS VIII-3 SMP N 1 BINJAI
}

\author{
Togi $^{1}$, Putri Theresia Sagala ${ }^{2}$ \\ ${ }^{1}$ Disen FMIPA, Universitas Negeri Medan (UNIMED), Sumatera Utara, Indonesia \\ ${ }^{2}$ FMIPA, Universitas Negeri Medan (UNIMED), Sumatera Utara, Indonesia \\ E-mail : togi17@gmail.com \\ Email: putri.theresia95@gmail.com
}

\begin{abstract}
ABSTRAK
Penelitian ini bertujuan untuk (1) Meningkatkan kemampuan penalaran matematis siswa melalui model discovery learning berbantuan Geogebra (2) Mengetahui ketuntasan siswa terhadap kemampuan penalaran matematis (3) Mengetahui respon siswa dalam pembelajaran dengan menerapkan model discovery learning berbantuan Geogebra. Jenis penelitian ini adalah penelitian tindakan kelas. Subjek penelitian yaitu siswa kelas VIII-3 yang bejumlah 36 orang. Objek penelitian adalah penerapan model discovery learning berbantuan geogebra untuk meningkatkan kemampuan penalaran matematis siswa pada materi koordinat kartesius di kelas VIII-3 SMP Negeri 1 Binjai. Penelitian ini terdiri dari dua siklus, dimana diakhir setiap siklus diberikan tes kemampuan penalaran matematis untuk mengetahui kemampuan penalaran matematis siswa. Berdasarkan hasil tes kemampuan awal yang dilakukan sebelum tindakan, diketahui tingkat kemampuan penalaran matematis siswa sangat rendah dengan nilai rata-rata kelas 41,32. Setelah pemberian tindakan pada siklus I, tingkat kemampuan penalaran matematis siswa adalah sedang dengan nilai rata-rata kelas 66,14 dan sebesar 55,56\% siswa yang mencapai ketuntasan yaitu tingkat kemampuan penalaran matematis minimal sedang. Selanjutnya setelah pelaksanaan tindakan siklus II, tingkat kemampuan penalaran matematis siswa adalah sedang dengan nilai rata-rata kelas 80,03 dan sebesar 88,89\% siswa yang mencapai ketuntasan yaitu tingkat kemampuan penalaran matematis minimal sedang. Respon siswa dalam pembelajaran dengan menerapkan model discovery learning berbantuan geogebra adalah positif dengan persentase pada siklus I sebesar 80,36\% dan pada siklus II sebesar 91,47\%. Berdasarkan uraian-uraian di atas dapat disimpulkan penalaran matematis siswa meningkat dengan menerapkan model discovery learning berbantuan geogebra pada materi koordinat kartesius Kata Kunci : Discovery Learning, Penalaran Matematis.
\end{abstract}

\begin{abstract}
This study aims to (1) improve students' reasoning skills by using discovery learning models with geogebra (2) to know students' thoroughness in mathematical reasoning skills 3) To know the response of students in learning by applying discovery learning models with geogebra. This research is a classroom action research (PTK). Subjects in this study were students of class VIII-3 totaling 36 students. While the object of this study is applying discovery learning models with geogebra to improve the students' mathematical reasoning skills. The study consisted of two cycles and tests given at the end of each cycle. From the
\end{abstract}

Togi, Putri Theresia Sagala. Penerapan Meningkatkan Kemampuan Penalaran Inspiratif. Vol 3, No. 3 Desember 2017.
Model Discovery Learning Berbantuan Geogebra untuk Matematis Siswa Kelas VIII-3 SMP N 1 Binjai. Jurnal 
results of the beginning test before the action given, students' mathematical reasoning skills level is very low and the average is 41,32. After the action given at cycles I, students'

mathematical reasoning skills level is medium with the average is 66,14 and 55,556\% of the total number of students who take the test have a minimal level of mathematical reasoning. After the action given at cycles II, students' mathematical reasoning skills level is medium with the averages is medium with the average is 80,03 and 88,89\% of the total number of students who take the test have a minimal level of mathematical reasoning. The response of students in learning by applying discovery learning models with geogebra is positively associated with the percentage of the first cycle of $80,36 \%$ and the second cycle of $91,47 \%$. Based on the results of students' mathematical reasoning skills from the first cycle to the second cycle can be concluded that the application of the discovery learning models can enhance students' mathematical reasoning skills.

Keywords: discovery learning, mathematical reasoning

\section{Pendahuluan}

Matematika sebagai salah satu mata pelajaran wajib dalam pendidikan formal mengambil peran sangat penting dalam dunia pendidikan. Setiap orang harus mempelajari matematika, karena matematika merupakan suatu sarana berpikir untuk mengkaji sesuatu secara logis dan sistematis. Salah satu kemampuan dalam tujuan pembelajaran matematika adalah kemampuan penalaran matematis. Kemampuan penalaran merupakan bagian yang sangat penting dalam belajar matematika, karena matematika terbentuk dan berkembang melalui proses penalaran. Menurut Liebeck (dalam Abdurrahman, 2009) "ada dua macam hasil belajar matematika yang harus dikuasai oleh siswa, perhitungan matematis (mathematics calculation) dan penalaran matematis (mathematics reasoning)".

Penalaran (reasoning) adalah suatu proses atau aktivitas berpikir untuk menarik kesimpulan atau membuat pernyataan baru yang benar berdasarkan pada pernyataan yang diketahui benar. Hasratuddin (2015) mengemukakan bahwa penalaran matematis adalah suatu proses berpikir dalam penarikan kesimpulan dengan alasan yang syah secara deduktif. Materi matematika dan penalaran matematis adalah dua hal yang tidak dapat dipisahkan, yaitu materi matematika dipahami melalui penalaran dan penalaran dipahami dan dilatihkan melalui belajar materi matematika. Bila kemampuan penalaran siswa tidak dikembangkan maka matematika akan menjadi materi yang hanya mengikuti prosedur atau hanya meniru contohcontoh tanpa mengetahui maknanya. Rizqi dan Surya (2017) menyatakan bahwa penalaran adalah suatu aktivitas atau proses, atau kemampuan berpikir untuk mengambil kesimpulan atau membuat pernyataan baru yang benar. Setiap kebutuhan masalah penalaran matematis untuk melatih kemampuan siswa. Kemampuan penalaran bisa dilakukan dengan memberi pertanyaan yang dirancang sehingga siswa terbiasa untuk menyelesaikan pertanyaan.

Menurut NCTM, bernalar matematik adalah suatu kebiasaan, dan seperti kebiasaan lainnya, maka ia mesti dikembangkan melalui pemakaian konsisten dan dalam berbagai konteks,
Togi, Putri Theresia Sagala. Penerapan Meningkatkan Kemampuan Penalaran Inspiratif. Vol 3, No. 3 Desember 2017.
Model Discovery Learning Berbantuan Geogebra untuk Matematis Siswa Kelas VIII-3 SMP N 1 Binjai. Jurnal 
NCTM menambahkan, orang yang bernalar dan berpikir secara analitik akan cenderung mengenal pola, struktur, atau keteraturan baik di dunia nyata maupun pada simbol-simbol. Orang ini gigih mencari tahu apakah pola itu terjadi secara kebetulan ataukah ada alasan tertentu. Ia membuat dugaan dan menyelidiki kebenaran atau ketidakbenaran dugaan itu. Membuat dan menyelidiki dugaan adalah hal yang sangat penting dalam matematika, karena melalui dugaan berbasis informasilah penemuan matematik sering terjadi. (Minarni, 2010).

Oleh karena begitu pentingnya penalaran dalam matematika, siswa dituntut memiliki kemampuan penalaran agar dapat memecahkan masalah yang akan mereka hadapi. Sesuai dengan pendapat Shadiq (2014) mengatakan bahwa seni bernalar memang sangat dibutuhkan di setiap segi dan setiap sisi kehidupan ini agar setiap warga bangsa dapat menemutunjukkan dan menganalisis setiap masalah yang muncul secara jernih; dapat memecahkan masalah dengan tepat; dapat menilai sesuatu secara kritis dan objektif; serta dapat mengemukakan pendapat maupun idenya secara runtut dan logis.

Namun tingginya tuntutan untuk memiliki kemampuan penalaran matematis tidak berbanding lurus dengan kenyataan di lapangan. Kemampuan penalaran siswa di Indonesia masih berada pada kategori rendah. Hasil laporan TIMSS juga menunjukkan bahwa jawaban benar siswa SMP Indonesia pada soal matematika di level pengetahuan $31 \%$, penerapan $23 \%$, sedangkan penalaran $17 \%$ (Mullis dkk, 2012). Penalaran yang rendah membuat siswa kesulitan belajar matematika. Hal ini sesuai pendapat Surya, Sabandar, Kusumah dan Darhim (2013) yang mengemukakan kesulitan yang diperoleh siswa adalah pada saat memahami, menggambar diagram, membaca grafik dengan benar, pemahaman konsep matematika formal, dan penyelesaian masalah matematika. Penyajian masalah yang tepat adalah hal mendasar dalam memahami masalah tersebut dan membuat rencana untuk menyelesaikannya.

Berdasarkan informasi yang diperoleh dari hasil wawancara dengan guru matematika SMP Negeri 1 Binjai bahwa kebanyakan siswa kesulitan jika diberikan soal yang bervariasi atau berbeda dari contoh yang telah diberikan. Siswa hanya terpaku pada langkahlangkah penyelesaian dari contoh dan hanya menghafal rumus untuk menyelesaikan soal. Misalnya, kebanyakan siswa bisa mencari keliling suatu persegi panjang bila diketahui nilai panjang dan lebarnya, namun jika diketahui nilai luas dan lebarnya, maka siswa akan kesulitan karena apa yang diketahui dalam soal tidak bisa langsung digunakan dalam rumus keliling persegi panjang. Ini menunjukkan kemampuan penalaran matematis siswa masih tergolong rendah.

Hal di atas didukung dari hasil tes yang diberikan peneliti pada saat observasi di kelas VIII-3 SMP Negeri 1 Binjai dengan soal-soal yang menguji penalaran siswa. Dari 36 siswa diperoleh nilai rata-rata sebesar 41,32 dengan

Togi, Putri Theresia Sagala. Penerapan Model Discovery Learning Berbantuan Geogebra untuk Meningkatkan Kemampuan Penalaran Matematis Siswa Kelas VIII-3 SMP N 1 Binjai. Jurnal Inspiratif. Vol 3, No. 3 Desember 2017. 
kriteria sangat rendah. Faktor kemungkinan menjadi penyebab timbulnya masalah tersebut adalah siswa masih kurang aktif selama proses pembelajaran, siswa cenderung hanya sebagai pendengar. Pernyataan ini didukung oleh Trianto (2011) bahwa proses pembelajaran hingga dewasa ini masih memberikan dominasi guru dan tidak memberikan akses bagi anak didik untuk berkembang secara mandiri melalui penemuan dalam proses berpikirnya.

Melihat rendahnya kemampuan penalaran matematis siswa, maka perlu adanya upaya atau tindakan untuk mengembangkan kemampuan penalaran matematis siswa. Siswa hendaknya ditempatkan sebagai individu yang kritis, kreatif, serta aktif dalam menggali dan menemukan sendiri konsep-konsep matematika. Oleh karena itu, diperlukan model pembelajaran yang tepat untuk mengembangkan kemampuan penalaran siswa. Salah satunya adalah model Discovery Learning.

Joolingen (2009) mengungkapkan bahwa pembelajaran discovery learning merupakan instrumen yang mendukung proses pengembangan kemamuan kognitif siswa dalam pembelajaran dan menjembatani lingkungan belajar siswa. Pembelajaran ini dipandang sebagai cara yang menjanjikan terutama dalam keterlibatan siswa secara aktif dalam proses belajar mengajar sehingga pengetahuan yang diperoleh siswa tidak sekedar dipindahkan oleh guru namun siswa mengembangkan sendiri pengetahuannya. Selanjutnya menurut Adelia \& Surya (2017) bahwa dalam pembelajaran penemuan (discovery), kegiatan atau pembelajaran dirancang sedemikian rupa sehingga siswa dapat menemukan konsep-konsep dan prinsipprinsip melalui proses mental sendiri.

Beberapa tahapan model discovery learning, yaitu stimulasi, identifikasi masalah, pengumpulan data, pengolahan data, verifikasi dan generalisasi. Pada tahapan mengidentifikasi masalah dan pengumpulan data, siswa diarahkan agar mampu memilih informasi apa saja yang dibutuhkan sehingga siswa akan terlatih memperkirakan jawaban, solusi atau kecenderungan serta menggunakan pola hubungan untuk menganalisis situasi. Pada tahapan pengolahan data, siswa akan melaksanakan perhitungan berdasarkan aturan atau rumus tertentu untuk mendapatkan suatu kesimpulan yang diharapkan. Pada tahapan ini juga membantu siswa melakukan penarikan kesimpulan berdasarkan keserupaan data atau proses, yang diikuti dengan tahap verifikasi untuk mengetahui keabsahan dari kesimpulan yang diperoleh.

Penerapan discovery learning dapat dilihat berdasarkan kesimpulan penelitian yang dilaksanakan oleh Alfieri, dkk (2011) berjudul Does Discovery Based Instruction Enhance Learning? Jurnal tersebut menyimpulkan bahwa dengan model discovery learning peserta didik akan secara aktif terlibat dan kontruktif yang optimal. Hal tersebut dianalisis dari: (1) Tugas yang diberikan kepada siswa dengan meminimalkan panduan dari guru; (2) Tugas yang diberikan membutuhkan ide-ide siswa sendiri untuk menjelaskan ide-ide yang akurat, guru hanya memberikan umpan

Togi, Putri Theresia Sagala. Penerapan Model Discovery Learning Berbantuan Geogebra untuk Meningkatkan Kemampuan Penalaran Matematis Siswa Kelas VIII-3 SMP N 1 Binjai. Jurnal Inspiratif. Vol 3, No. 3 Desember 2017. 
balik; (3) Tugas-tugas yang diberikan dikerjakan sesuai dengan panduan agar berhasil. Tugas guru dalam pembelajaran tersebut adalah memberikan umpan balik, pengaturan ruangan kelas, membuat contoh sesuai dengan konten-konten yang diperlukan saja dan mempersiapkan pembelajaran.

Selain pemilihan model pembelajaran, pemanfaatan media yaitu teknologi komputer dalam proses pembelajaran juga merupakan salah satu upaya meningkatkan kemampuan penalaran siswa. Berdasarkan wawancara dengan guru matematika SMP Negeri 1 Binjai, bahwa pembelajaran di kelas sangat jarang menggunakan media pembelajaran, terutama media yang berbasis teknologi komputer.

Objek-objek dalam matematika bersifat abstrak sehingga memunculkan berbagai kesulitan dalam mempelajarinya, terutama bagi siswa di kelas tingkat rendah. Hal tersebut mendorong perlunya penggunaan media pembelajaran. Dengan penggunaan media, matematika dapat dikemas menjadi pelajaran yang menarik dan mudah dimengerti. Salah satu media berbasis teknologi komputer yang dapat dimanfaatkan dalam pembelajaran matematika, khususnya geometri adalah Geogebra. Menurut Hohenwarter (dalam Mahmudi 2010) Geogebra adalah program komputer (software) untuk membelajarkan matematika khususnya geometri dan aljabar.

Dengan menggunakan geogebra memberikan banyak manfaat seperti (1) lukisan - lukisan geometri yang dihasilkan lebih cepat dari pada menggunakan pensil, penggaris dan jangka, (2) dapat dianimasikan dan digerakan dengan dragging pada objek geometri yang memberikan pengalaman visual, (3) dimanfaatkan sebagai balikan/evaluasi untuk memastikan lukisan yang dibuat benar, (4) mempermudah guru/siswa untuk menyelidiki atau menunjukkan sifat -sifat yang berlaku pada suatu objek geometri (Mahmudi, 2010).

Berdasarkan permasalahan yang telah diuraikan di atas, kemampuan penalaran matematis siswa perlu ditingkatkan dan model discovery learning berbantuan geogebra sangat memungkinkan untuk menjadi penyelesaiannya.

\section{Metode Penelitian}

\section{Lokasi dan Waktu Penelitian}

Penelitian ini dilakukan di SMP Negeri 1 Binjai di kelas VIII-3. Adapun alasan peneliti memilih lokasi penelitian ini adalah dikarenakan di lokasi tersebut peneliti menemukan masalah. Penelitian dilaksanakan pada tahun ajaran 2017/2018.

\section{Subjek Penelitian}

Subjek dalam penelitian ini adalah siswa kelas VIII-3 yang berjumlah 36 siswa.

\section{Objek Penelitian}

Objek dalam penelitian ini adalah kemampuan penalaran matematika siswa dengan menerapkan model discovery learning pada pokok bahasan koordinat kartesius.

\section{Jenis Penelitian}

Togi, Putri Theresia Sagala. Penerapan Model Discovery Learning Berbantuan Geogebra untuk Meningkatkan Kemampuan Penalaran Matematis Siswa Kelas VIII-3 SMP N 1 Binjai. Jurnal Inspiratif. Vol 3, No. 3 Desember 2017. 
Jenis penelitian yang dilaksanakan adalah Penelitian Tindakan Kelas (PTK) atau Classroom Action Research (CAR) dengan menerapkan discovery learning, dilakukan dengan tujuan meningkatkan kemampuan penalaran matematika siswa. Penelitian ini merupakan penelitian yang sifatnya kolaboratif karena adanya kerjasama antara peneliti dengan pendidik mata pelajaran matematika.

\section{Teknik Pengumpulan Data}

\section{Tes Kemampuan Penalaran}

Tes yang diberikan berbentuk tes uraian (essay test) yang bertujuan untuk mengetahui dan mengukur peningkatan kemampuan penalaran siswa setelah mengikuti pembelajaran matematika dengan model discovery learning. Sebelum digunakan terlebih dahulu peneliti memvalidkan tes tersebut berdasarkan para ahli sebagai validator.

\section{Observasi}

Observasi dilakukan dengan cara melakukan pengamatan selama proses pembelajaran berlangsung. Observasi dilakukan untuk mengetahui apakah proses pembelajaran dan kondisi belajar sudah terlaksana sesuai dengan Rencana Pelaksanaan Pembelajaran yang telah dirancang. Observasi yang dilakukan bersifat langsung dari awal sampai akhir tindakan dilaksanakan.

\section{Angket Respon Siswa}

Angket digunakan untuk mengungkap respon siswa terhadap proses pembelajaran dengan menggunakan model discovery learning berbantuan geogebra dan perangkat pembelajaran dengan cara memberi tanda centang $(\sqrt{ })$ pada kolom yang tersedia untuk masing-masing pertanyaan yang diajukan. Angket ini diberikan pada siswa di akhir pokok bahasan.

\section{Teknik Analisis Data}

\section{Reduksi Data}

Setelah tes kemampuan penalaran matematis siswa mengenai koordinat kartesius diberikan, selanjutnya dikoreksi, dipelajari dan ditelaah untuk menggolongkan data dan mengorganisasikan jawaban siswa. Kegiatan reduksi ini bertujuan untuk melihat kesalahan jawaban siswa dan permasalahan yang dialami siswa dalam menyelesaikan soal dan tindakan apa yang dilakukan untuk memperbaiki kesalahan tersebut.

\section{Paparan Data}

Memaparkan data yang sistematis dan interaktif akan memudahkan pemahaman terhadap apa yang telah terjadi sehingga memudahkan penarikan kesimpulan atau menentukan tindakan yang akan dilakukan selanjutnya.

\section{Penarikan Kesimpulan}

Setelah dipaparkan, data kemudian disimpulkan. Kesimpulan yang diperoleh dijadikan dasar untuk pelaksanaan siklus berikutnya dan perlu tidaknya siklus berikutnya dilanjutkan atas dasar permasalahan yang ada. Siklus penelitian ini berhenti apabila dipenuhi target penelitian dalam arti penelitian ini berhasil.

Indikator keberhasilan dalam penelitian ini dapat dilihat dari:

Togi, Putri Theresia Sagala. Penerapan Model Discovery Learning Berbantuan Geogebra untuk Meningkatkan Kemampuan Penalaran Matematis Siswa Kelas VIII-3 SMP N 1 Binjai. Jurnal Inspiratif. Vol 3, No. 3 Desember 2017. 
1. Target pencapaian dalam siklus yaitu $85 \%$ siswa dalam kelas memperoleh skor $\geq 65$

2. Guru dalam melaksanakan proses pembelajaran minimal berkategori baik, hal tersebut dilihat dari hasil persentase skor observasi aktivitas guru yaitu $\geq 2,2$

3. Persentase respon siswa terhadap pembelajaran melalui model discovery learning berbantuan geogebra memberi respon positif $\geq$ $80 \%$ (kategori positif)

\section{Pembahasan penelitian}

\section{Permasalahan I}

Penelitian ini dilaksanakan di kelas VIII-3 SMP Negeri 1 Binjai dengan jumlah siswa 36 orang. Masalah dalam penelitian ini yaitu kemampuan penalaran matematis siswa yang masih rendah yang terlihat pada hasil tes kemampuan awal yang diberikan peneliti kepada siswa kelas VIII-3 tersebut.

Berdasarkan hasil tes kemampuan awal terlihat bahwa kemampuan penalaran matematis siswa masih sangat rendah. Hal ini terlihat dari rata-rata kemampuan siswa sekitar 41,32 dan hanya 1 dari 36 siswa $(2,78 \%)$ yang memiliki kemampuan penalaran matematis dengan kategori tinggi, 5 dari 36 siswa $(13,89 \%)$ memiliki kemampuan penalaran matematis dengan kategori sedang, 7 dari 36 siswa $(19,44 \%)$ memiliki kemampuan penalaran matematis siswa dengan kategori rendah dan 23 dari $36(63,89 \%)$ siswa memiliki kemampuan penalaran matematis sangat rendah. Sedangkan persentase ketuntasan klasikalnya adalah $16,67 \%$. Menyadari hal tersebut diperlukan suatu upaya untuk meningkatkan kemampuan penalaran matematis siswa. Upaya yang dapat dilakukan untuk meningkatkannya adalah dengan menerapkan model discovery learning.

\section{Hasil Penelitian Siklus I}

Hasil jawaban tes kemampuan penalaran matematis siswa dilihat dari setiap indikator pada kemampuan penalaran matematis dapat dilihat dari gambar grafik sebagai berikut.

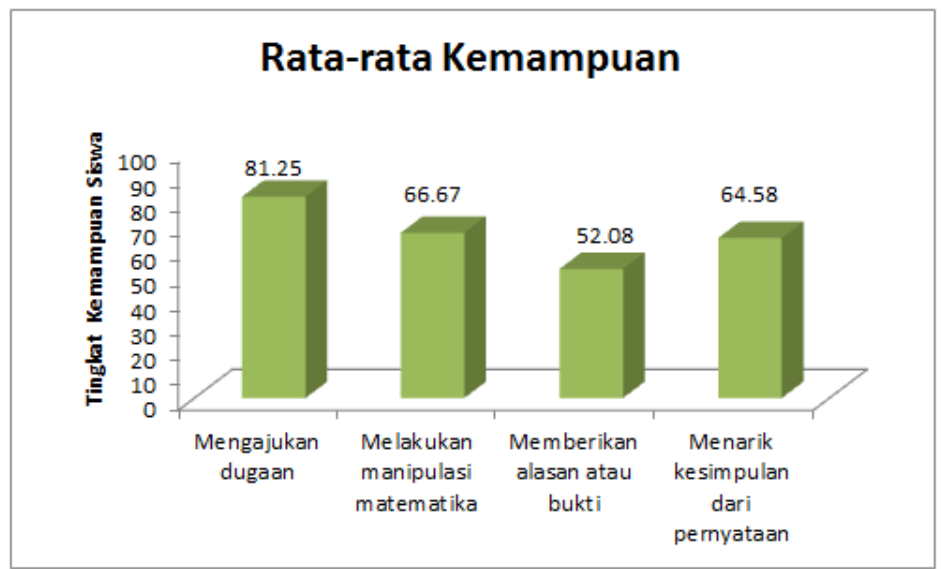
Gambar 1. Tingkat Kemampuan Siswa Tiap Indikator Kemampuan
Penalaran Matematis pada Siklus I

Togi, Putri Theresia Sagala. Penerapan Model Discovery Learning Berbantuan Geogebra untuk Meningkatkan Kemampuan Penalaran Matematis Siswa Kelas VIII-3 SMP N 1 Binjai. Jurnal Inspiratif. Vol 3, No. 3 Desember 2017. 
Adapun hasil tes kemampuan dalam grafik berikut. penalaran matematis siklus I disajikan

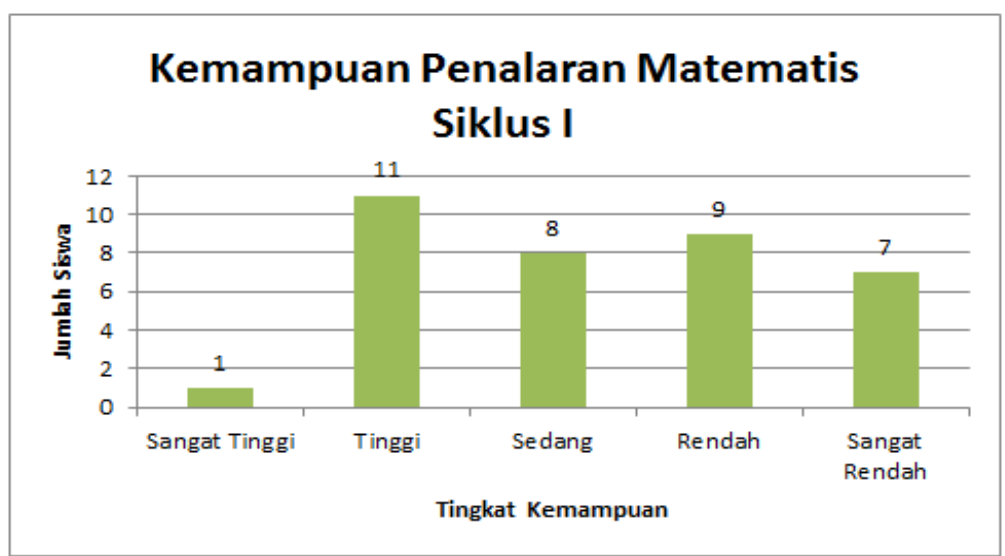

\section{Gambar 2 Diagram Tingkat Kemampuan Penalaran Matematis Siswa Pada Siklus I}

Berdasarkan hasil analisis data dari tes kemampuan penalaran matematis I, kemampuan penalaran siswa meningkat dari hasil tes kemampuan penalaran awal. Hal ini dapat dilihat dari peningkatan ratarata kemampuan penalaran dari 41,32 (sangat rendah) menjadi 66,14 (sedang). Adapun jumlah siswa yang dikatakan tuntas atau berada pada tingkat kemampuan minimal sedang adalah 20 siswa dengan persentase ketuntasan klasikal sebesar 55,56\%. Karena belum tercapainya kriteria keberhasilan yang direncanakan pada bab III yakni ketuntasan klasikal kelas minimal mencapai $\geq 85 \%$ maka penelitian ini berlanjut ke siklus II.

\section{Observasi Pembelajaran}

Hasil observasi guru siklus I pertemuan pertama diperoleh nilai 2,54 dan pada pertemuan kedua diperoleh nilai 2,91. Sehingga diperoleh rata-rata nilai 2,72 yang berarti proses pembelajaran yang dilakukan oleh guru sudah berjalan dengan baik. Semua hasil yang diperoleh dalam kegiatan observasi oleh observer akan dijadikan sebagai bahan masukan dalam melakukan perbaikan dalam kegiatan pembelajaran selanjutnya.

\section{Respon Siswa}

Persentase respon siswa dalam pembelajaran dengan menerapkan model discovery learning adalah sebesar 80,36\% . Dengan mengacu pada kriteria yang sudah ditetapkan pada Bab III, maka dapat dikatakan bahwa respon siswa dalam pembelajaran dengan menerapkan model discovery learning adalah positif.

Togi, Putri Theresia Sagala. Penerapan Model Discovery Learning Berbantuan Geogebra untuk Meningkatkan Kemampuan Penalaran Matematis Siswa Kelas VIII-3 SMP N 1 Binjai. Jurnal Inspiratif. Vol 3, No. 3 Desember 2017. 
Tabel 1. Hasil Penelitian Siklus I

\begin{tabular}{|c|c|c|c|}
\hline Aspek & $\begin{array}{c}\text { Kriteria } \\
\text { Keberhasilan }\end{array}$ & Hasil & Keterangan \\
\hline $\begin{array}{l}\text { Kemampuan } \\
\text { Penalaran } \\
\text { Matematis } \\
\text { Siswa }\end{array}$ & $\begin{array}{l}\text { Terdapat } \geq 85 \% \\
\text { siswa berada pada } \\
\text { tingkat kemampuan } \\
\text { minimal sedang. }\end{array}$ & $\begin{array}{l}\text { Terdapat } 55,56 \% \\
\text { siswa berada pada } \\
\text { tingkat kemampuan } \\
\text { minimal sedang. }\end{array}$ & $\begin{array}{lr}\text { Kemampuan } & \text { belum } \\
\text { memenuhi } & \text { kriteria } \\
\text { keberhasilan } & \text { maka } \\
\text { berlanjut ke siklus II. } & \end{array}$ \\
\hline $\begin{array}{l}\text { Kemampuan } \\
\text { Guru dalam } \\
\text { Mengelola } \\
\text { Pembelajaran }\end{array}$ & $\begin{array}{l}\text { Proses pembelajaran } \\
\text { minimal berkategori } \\
\text { baik (skor } \geq 2,2 \text { ). }\end{array}$ & $\begin{array}{l}\text { Skor kemampuan } \\
\text { guru 2,72 (baik). }\end{array}$ & $\begin{array}{l}\text { Siklus dilanjutkan dengan } \\
\text { memperbaiki kelemahan } \\
\text { guru. }\end{array}$ \\
\hline $\begin{array}{l}\text { Respon Siswa } \\
\text { dalam } \\
\text { Pembelajaran }\end{array}$ & $\begin{array}{lr}\text { Banyak siswa } & \text { yang } \\
\text { memberi } & \text { respon } \\
\text { positif } \geq 80 \% & \end{array}$ & $\begin{array}{lr}\text { Persentase } & \text { respon } \\
\text { siswa } & 80,36 \% \\
\text { (respon positif) }\end{array}$ & $\begin{array}{l}\text { Siklus dilanjutkan dengan } \\
\text { memperbaiki kelemahan } \\
\text { pembelajaran. }\end{array}$ \\
\hline
\end{tabular}

Berdasarkan tabel di atas, dapat mempertahankan serta meningkatkan dilihat bahwa masih terdapat aspek yang keberhasilan yang terjadi pada siklus I.

belum memenuhi kriteria keberhasilan yaitu aspek kemampuan penalaran

\section{Hasil Penelitian Siklus II}

Hasil jawaban tes kemampuan penalaran matematis siswa dilihat dari setiap indikator pada kemampuan penalaran matematis siklus II dapat dilihat dari gambar grafik sebagai berikut.

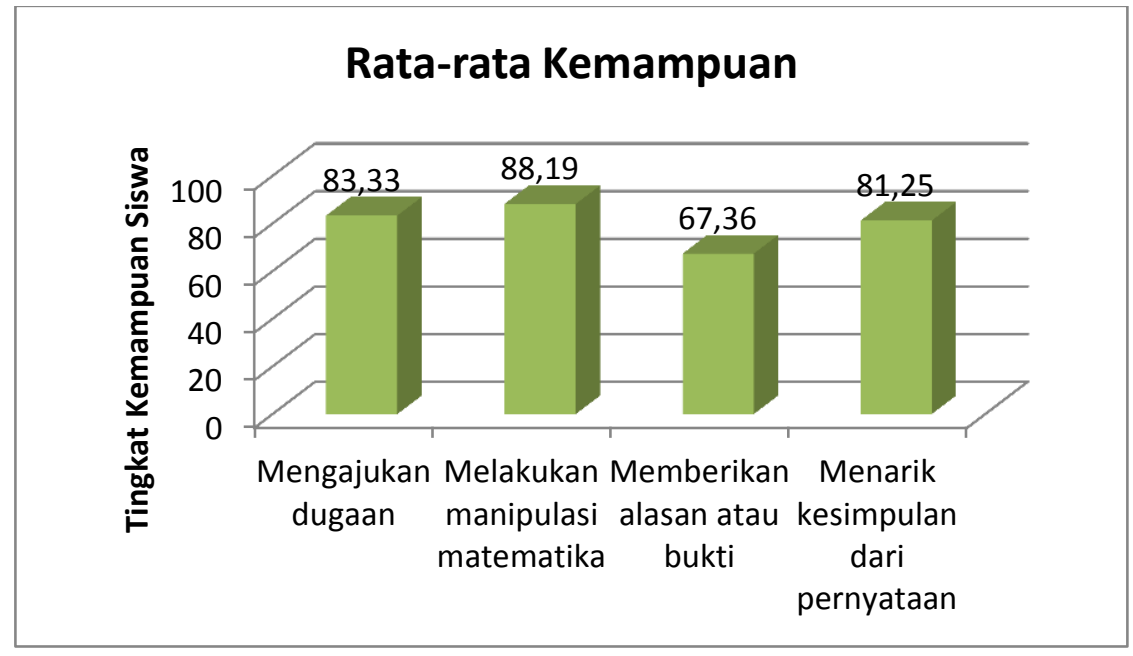

\section{Gambar 3. Tingkat Kemampuan Siswa Tiap Indikator Kemampuan Penalaran Matematis pada Siklus II}

Secara keseluruhan, tingkat kemampuan penalaran matematis siswa pada tes kemampuan penalaran matematis siklus II disajikan dalam grafik berikut.
Togi, Putri Theresia Sagala. Penerapan Meningkatkan Kemampuan Penalaran Inspiratif. Vol 3, No. 3 Desember 2017.
Model Discovery Learning Berbantuan Geogebra untuk Matematis Siswa Kelas VIII-3 SMP N 1 Binjai. Jurnal 


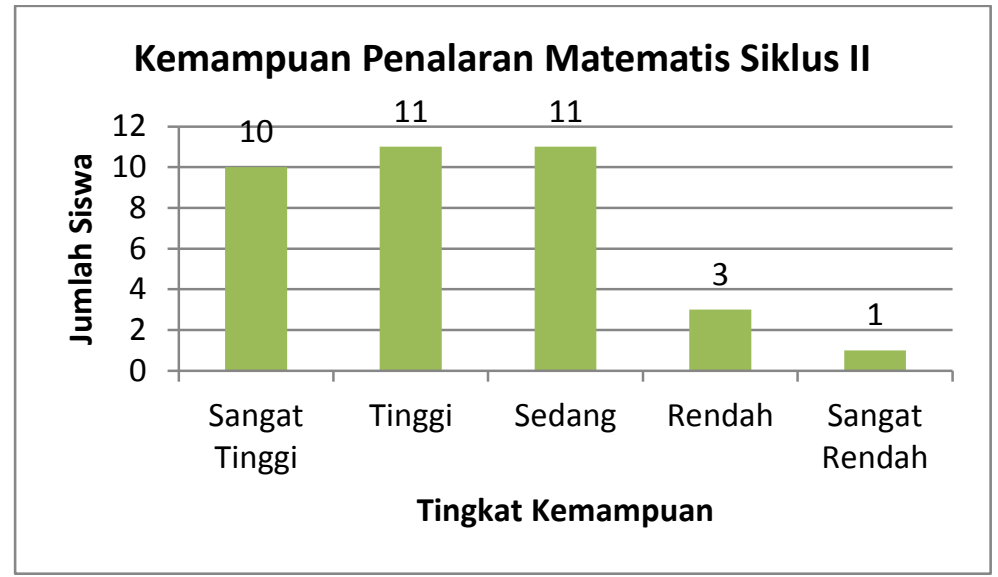

\section{Gambar 4. Diagram Tingkat Kemampuan Penalaran Matematis Siswa Pada Siklus II}

Secara keseluruhan, tingkat kemampuan penalaran matematis siswa pada tes kemampuan penalaran matematis II sudah dalam kategori tinggi dengan nilai rata-rata 80,03 . Sebanyak 10 orang siswa $(27,78 \%)$ berada pada kategori sangat tinggi, 11 orang siswa $(30,56 \%)$ berada pada kategori tinggi, 11 orang siswa $(30,56 \%)$ berada pada kategori sedang, 3 orang siswa $(8,33 \%)$ berada pada kategori rendah, 1 orang siswa $(2,78 \%)$ berada pada kategori sangat rendah. Dari hasil tersebut terlihat bahwa 32 dari 36 orang siswa $(88,89 \%)$ telah mencapai standar kemampuan penalaran matematis yang ditargetkan, yaitu siswa yang memperoleh nilai $\geq 65$ dengan kategori minimal sedang. Itu artinya standar keberhasilan penelitian sudah tercapai.

\section{Observasi Pembelajaran}

Berdasarkan hasil observasi guru siklus II, pertemuan pertama diperoleh nilai 3,27 dan pada pertemuan kedua diperoleh nilai 3,45 . Sehingga diperoleh rata-rata nilai 3,36 yang berarti proses pembelajaran yang dilakukan oleh guru sudah berjalan sangat baik.

\section{Respon Siswa}

Persentase respon siswa dalam pembelajaran dengan menerapkan model discovery learning berbantuan geogebra adalah sebesar $91,47 \%$. Dengan mengacu pada kriteria yang sudah ditetapkan pada Bab III, maka dapat dikatakan bahwa respon siswa dalam pembelajaran dengan menerapkan model discovery learning berbantuan geogebra adalah positif.

Togi, Putri Theresia Sagala. Penerapan Model Discovery Learning Berbantuan Geogebra untuk Meningkatkan Kemampuan Penalaran Matematis Siswa Kelas VIII-3 SMP N 1 Binjai. Jurnal Inspiratif. Vol 3, No. 3 Desember 2017. 
Tabel 2. Hasil Penelitian Siklus II

\begin{tabular}{|c|c|c|c|}
\hline Aspek & $\begin{array}{c}\text { Kriteria } \\
\text { Keberhasilan }\end{array}$ & Hasil & Keteran \\
\hline $\begin{array}{l}\text { Kemampuan } \\
\text { Penalaran } \\
\text { Matematis Siswa }\end{array}$ & $\begin{array}{l}\text { Terdapat } \geq 85 \% \\
\text { siswa berada pada } \\
\text { tingkat kemampuan } \\
\text { minimal sedang. }\end{array}$ & $\begin{array}{l}\text { Terdapat } 88,89 \% \\
\text { siswa berada pada } \\
\text { tingkat kemampuan } \\
\text { minimal sedang. }\end{array}$ & $\begin{array}{l}\text { Siklus berhenti karena } \\
\text { indikator keberhasilan } \\
\text { sudah tercapai. }\end{array}$ \\
\hline $\begin{array}{l}\text { Kemampuan } \\
\text { Guru dalam } \\
\text { Mengelola } \\
\text { Pembelajaran }\end{array}$ & $\begin{array}{l}\text { Proses pembelajaran } \\
\text { minimal berkategori } \\
\text { baik (skor } \geq 2,2 \text { ) }\end{array}$ & $\begin{array}{l}\text { Skor kemampuan guru } \\
3,47 \text { (sangat baik). }\end{array}$ & $\begin{array}{l}\text { Siklus berhenti karena } \\
\text { indikator keberhasilan } \\
\text { sudah tercapai. }\end{array}$ \\
\hline $\begin{array}{l}\text { Respon Siswa } \\
\text { dalam } \\
\text { Pembelajaran }\end{array}$ & $\begin{array}{l}\text { Banyak siswa yang } \\
\text { memberi respon } \\
\text { positif } \geq 80 \%\end{array}$ & $\begin{array}{ll}\text { Persentase } & \text { respon } \\
\text { siswa } 87,10 \% & \text { (respon } \\
\text { positif) } & \end{array}$ & $\begin{array}{l}\text { Siklus berhenti karena } \\
\text { indikator keberhasilan } \\
\text { sudah tercapai. }\end{array}$ \\
\hline
\end{tabular}

Tabel 3. Deskripsi Hasil Rata-rata Kemampuan Penalaran Matematis Siswa Tiap Tes

\begin{tabular}{|l|l|c|c|c|}
\hline Nilai & Tingkat Kemampuan & Tes Awal & Siklus I & Siklus II \\
\hline $90-100$ & Sangat Tinggi & 0 & 1 & 10 \\
\hline $80-89$ & Tinggi & 1 & 11 & 11 \\
\hline $65-79$ & Sedang & 5 & 8 & 11 \\
\hline $55-64$ & Rendah & 7 & 9 & 3 \\
\hline $0-54$ & Sangat Rendah & 23 & 7 & 1 \\
\hline $\begin{array}{l}\text { Jumlah } \\
\text { Rata-rata Kemampuan Penalaran } \\
\text { Matematis Siswa }\end{array}$ & 41,32 & 66,14 & 80,03 \\
\hline
\end{tabular}

Berdasarkan tabel diatas, terlihat bahwa semua aspek sudah mencapai kriteria keberhasilan. Karena indikator keberhasilan dalam penelitian ini telah tercapai, maka tujuan dari penelitian ini telah tercapai sehingga pembelajaran dihentikan dan tidak dilanjutkan ke siklus berikutnya. Dengan demikian berdasarkan hasil observasi dan tes kemampuan penalaran matematis siswa dapat disimpulkan bahwa penerapan model discovery learning berbantuan geogebra dalam pembelajaran matematika dapat meningkatkan kemampuan penalaran matematis siswa pada materi koordinat kartesius kelas VIII-3 SMP Negeri 1 Binjai.

Sesuai dengan penelitian terdahulu yang relevan yang dilakukan oleh Ahmad (2015) dimana dengan menggunakan model discovery learning dengan pendekatan saintifik diperoleh

Togi, Putri Theresia Sagala. Penerapan Model Discovery Learning Berbantuan Geogebra untuk Meningkatkan Kemampuan Penalaran Matematis Siswa Kelas VIII-3 SMP N 1 Binjai. Jurnal Inspiratif. Vol 3, No. 3 Desember 2017. 
peningkatan kemampuan penalaran matematis siswa. Selain itu penelitian dari Burais (2016) yang berjudul Peningkatan Kemampuan Penalaran Matematis Siswa melalui Model Discovery Learning. Hasil yang diperoleh bahwa peningkatan kemampuan penalaran matematis siswa yang memperoleh pembelajaran dengan model discovery learning lebih baik dari siswa yang memperoleh pembelajaran konvensional.

\section{Kesimpulan dan Saran}

\section{Kesimpulan}

Berdasarkan hasil penelitian dan pembahasan yang dijelaskan pada Bab IV diperoleh kesimpulan sebagai berikut:

1. Berdasarkan tes kemampuan penalaran matematis, diperoleh bahwa penerapan model discovery learning berbantuan geogebra dapat meningkatkan kemampuan penalaran matematis siswa kelas VIII-3 SMP Negeri 1 Binjai pada pokok bahasan koordinat kartesius. Pada tes kemampuan awal diperoleh rata-rata kemampuan penalaran matematis siswa sebesar 41,32. Pada siklus I diperoleh rata-rata kemampuan penalaran matematis siswa meningkat menjadi 66,14. Dan pada siklus II diperoleh rata-rata kemampuan penalaran matematis siswa meningkat menjadi 80,03.

2. Berdasarkan dari hasil penelitian terjadi peningkatan persentase ketuntasan klasikal. Pada tes kemampuan awal sebanyak 6 siswa $(16,67 \%)$ yang tuntas (memperoleh nilai kemampuan $\geq 65$ atau memiliki tingkat kemampuan penalaran matematis berada dalam kategori minimal sedang) meningkat menjadi 20 siswa $(55,56 \%)$ yang tuntas pada siklus I dan pada siklus II mengalami menjadi 32 siswa $(88,89 \%)$. Hal ini menunjukkan bahwa ketuntasan klasikal siswa sudah melebihi target yaitu $85 \%$.

3. Respon siswa terhadap komponen dan kegiatan pembelajaran dengan menggunakan model discovery learning berbantuan geogebra adalah positif. Hal ini dilihat dari persentase respon siswa selama proses pembelajaran yang berlangsung pada siklus I sebesar $80,36 \%$ dan pada siklus II sebesar 91,47\%.

\section{Saran}

Berdasarkan hasil penelitian, pembahasan serta kesimpulan, maka peneliti memberikan beberapa saran sebagai berikut:

1. Kepada guru matematika khususnya guru matematika SMP Negeri 1 Binjai disarankan menerapkan model discovery learning berbantuan geogebra sebagai alternatif untuk meningkatkan kemampuan penalaran matematis siswa, khususnya pada materi koordinat kartesius dan perlu dicoba untuk materi yang lain.

2. Guru sebaiknya berupaya untuk selalu melibatkan siswa untuk lebih aktif dan membuat suasana yang menyenangkan dalam proses belajar mengajar sehingga siswa tertarik dan termotivasi dalam belajar serta dapat mengkondisikan siswa dalam keadaan nyaman dan siap untuk belajar, karena kondisi yang nyaman dapat

Togi, Putri Theresia Sagala. Penerapan Model Discovery Learning Berbantuan Geogebra untuk Meningkatkan Kemampuan Penalaran Matematis Siswa Kelas VIII-3 SMP N 1 Binjai. Jurnal Inspiratif. Vol 3, No. 3 Desember 2017. 
menciptakan suasana yang efektif dan efisien untuk belajar.

3. Kepada siswa khususnya siswa SMP Negeri 1 Binjai diharapkan untuk lebih aktif dalam proses pembelajaran, lebih banyak berlatih menyelesaikan soal-soal dan lebih berani untuk mengungkapkan ide dan pendapat saat berdiskusi.

4. Bagi peneliti lain yang ingin melakukan penelitian sejenis dapat melakukan penelitian lebih lanjut mengenai penggunaan model discovery learning berbantuan geogebra terhadap peningkatan kemampuan belajar lainnya serta penerapannya pada pokok bahasan yang berbeda.

\section{DAFTAR PUSTAKA}

Adelia, W.S., \& Surya, E. 2017. Resolution to Increase Capacity by using Math Students Learning Guided Discovery Learning ( $g d l)$. International Journal of Sciences: Basic and Applied Research (IJSBAR). Volume. 34, No. 1, https://www.researchgate.net/publ ication/318561469

Adurrahman, Mulyono. 2009. Pendidikan Bagi Anak Berkesulitan Belajar. Jakarta: Rineka Cipta

Ahmad, Habriah. 2015. Peningkatan Kemampuan Penalaran Matematika Materi Trigonometri Melalui Penerapan Model Pembelajaran Discovery Learning dengan Pendekatan Saintifik pada Kelas X SMA Negeri 11
Makassar. Jurnal Daya Matematis Vol 3 No. 3: 299-307

Alfieri, dkk. 2011. Does Discovery Learning-Based Instruction Enhance Learning?. Educational Psychology, 103 (1):1-18

Asmani, Jamal. 2011. Penelitian Tindakan Kelas. Yogyakarta: Laksana

Burais, Listika, dkk. 2016. Peningkatan Kemampuan Penalaran Matematis Siswa melalui Model Discovery Learning. Jurnal Didaktik Matematika Vol. 3 No. 1: $77-86$

Hasratuddin. 2015. Mengapa Harus Belajar Matematika?. Medan : Perdana Publishing

Joolingen, W. van. 2009. Cognitive Tools for Discovery Learning. International Journal of Artificial Intelegence in Education, 10, 385 397.

Mahmudi, Ali. 2010. Membelajarkan Geometri dengan Program GeoGebra. Makalah disampaikan pada Seminar Nasional Matematika dan Pendidikan Matematika. FMIPA UNY

Minarni, Ani. 2010. Peran Penalaran Matematik untuk Meningkatkan Kemampuan Pemecahan Masalah Matematik Siswa. Makalah. Seminar Nasional Matematika dan Pendidikan Matematika. FMIPA UNY

Togi, Putri Theresia Sagala. Penerapan Model Discovery Learning Berbantuan Geogebra untuk Meningkatkan Kemampuan Penalaran Matematis Siswa Kelas VIII-3 SMP N 1 Binjai. Jurnal Inspiratif. Vol 3, No. 3 Desember 2017. 
Mullis, dkk. 2012. TIMSS 2011 International Result in Mathematics. Chestnut Hill, MA: TIMSS \& PIRLS International Study Center. Boston College.

Rizqi, N.R. and Surya, E. 2017. An Analysis of Students' Mathematical Reasoning Ability In VIII Grade of Sablina Tembung Junior High School. International Journal of Advance Research and Innovative Ideas in Education. 3(2), 333527-3533.

Shadiq, Fadjar. 2014. PEMBELAJARAN MATEMATIKA; Cara Meningkatkan Kemampuan Berpikir Siswa. Yogyakarta: Graha Ilmu

Surya, E. Sabandar, J., Kusumah, Y.S. dan Darhim (2013). Improving of Junior High School Visual Thinking Representation Ability in Mathematical Problem Solving by CTL. Indonesian Mathematiocal Society Journal on Mathematics Education Journal , 4(1), 113-126.

Trianto. 2011. Mendesain Model Pembelajaran Inovatif-Progresif; Konsep, Landasan, dan Implementasinya pada Kurikulum Tingkat Satuan Pendidikan (KTSP). Jakarta: Kencana

Togi, Putri Theresia Sagala. Penerapan Model Discovery Learning Berbantuan Geogebra untuk Meningkatkan Kemampuan Penalaran Matematis Siswa Kelas VIII-3 SMP N 1 Binjai. Jurnal Inspiratif. Vol 3, No. 3 Desember 2017. 